\title{
Enhancement of active MMP release and invasive activity of lymph node metastatic tongue cancer cells by elevated signaling via the TNF- $\alpha$-TNFR1-NF- $\kappa$ B pathway and a possible involvement of angiopoietin-like 4 in lung metastasis
}

\author{
TAKUYA TANAKA ${ }^{1}$, TAKAHISA IMAMURA ${ }^{2}$, MASAKAZU YONEDA $^{1,2}$, ATSUSHI IRIE $^{3}$, \\ HIDENAO OGI ${ }^{1}$, MASASHI NAGATA ${ }^{1}$, RYOJI YOSHIDA ${ }^{1}$, DAIKI FUKUMA ${ }^{1}$, KENTA KAWAHARA ${ }^{1}$, \\ MASANORI SHINOHARA ${ }^{1}$ and HIDEKI NAKAYAMA ${ }^{1}$ \\ Departments of ${ }^{1}$ Oral and Maxillofacial Surgery, ${ }^{2}$ Molecular Pathology, and ${ }^{3}$ Immunogenetics, \\ Faculty of Life Sciences, Kumamoto University, Kumamoto 860-8556, Japan
}

Received May 17, 2016; Accepted July 22, 2016

DOI: 10.3892/ijo.2016.3653

\begin{abstract}
To study the role of TNF- $\alpha$ in tongue cancer metastasis, we made highly metastatic cells from a human oral squamous cell carcinoma cell line (SAS) by repeating the passage in which the cells were injected into a nude mouse tongue and harvested from metastasized cervical lymph nodes. Cancer cells after 5 passages (GSAS/N5) increased invasive activity 7 -fold in a TNF- $\alpha$ receptor 1 (TNFR1)dependent manner and enhanced mRNA expression of TNF- $\alpha$ and TNFR1. In the highly metastatic cells, NF- $\mathrm{KB}$ activation was upregulated via elevated phosphorylation of Akt and $\mathrm{IKK} \alpha / \beta$ in the signaling pathway and secretion of TNF- $\alpha$, active MMP-2 and MMP-9 increased. Suppression of increase of TNF- $\alpha$ mRNA expression and MMP secretion by NF- $\kappa B$ inhibitor NBD peptide suggested a positive feedback loop in GSAS/N5 cells; TNF- $\alpha$ activates NF- $\kappa B$ and activated NF- $\kappa B$ induces further TNF- $\alpha$ secretion, leading to increase of active MMP release and promotion of invasion and metastasis of the cells. GSAS/N5 cells that had been injected into the nude mouse tongue and harvested from metastasized lungs multiplied angiopoietin-like 4 (Angpt14) expression with enhanced
\end{abstract}

Correspondence to: Dr Hideki Nakayama, Department of Oral and Maxillofacial Surgery, Faculty of Life Sciences, Kumamoto University, 1-1-1 Honjo, Kumamoto 860-8556, Japan

E-mail: hinakayam@gmail.com

Abbreviations: OSCC, oral squamous cell carcinoma; TNF- $\alpha$, tumor necrosis factor- $\alpha$; GSAS, GFP expressing SAS cell; GSAS/N3, lymph node metastasized GSAS after three passages; GSAS/N5, lymph node metastasized GSAS after five passages; GSAS/L, lung metastasized GSAS/N5; NBD, NEMO-binding domain; TNFR1, tumor necrosis factor- $\alpha$-receptor 1

Key words: Akt, IKK $\alpha / \beta$, microarray, migration, metastasis, p50/p65, receptor migration activity, which indicated a possible involvement of Angpt14 in lung metastasis of the cells. These results suggest that TNF- $\alpha$ and Angpt14 promote metastasis of the oral cancer cells, thus, these molecules may be therapeutic targets for patients with tongue cancer.

\section{Introduction}

The American Cancer Society estimated 45,780 new cases of oral cavity and pharyngeal cancer, and 8,650 deaths from these tumors, in 2015 in the United States (1). By advances in surgery and radiation therapy, the 5-year survival rate for oropharyngeal cancer has increased to $66 \%$, but the rate is still unsatisfactory in comparison with some other site cancers including prostate, thyroid and breast; the rates of these types of cancer are $>90 \%$ (1). A primary cause for the unfavorable prognosis is patient death from the cancer metastasized at regional and distant sites (2-5). Squamous cell carcinoma (SCC) accounts for approximately $90 \%$ of oral and oropharyngeal malignancies in the United States and tongue is a common site of the malignant diseases $(6,7)$. The rate of nodal metastasis is higher in tongue cancer patients than oral cavity cancer patients whose rate is $30 \%$ on their initial evaluation $(8,9)$. Several studies have shown a high rate of occult nodal metastasis (20-40\%) in tongue SCC patients with no evidence of regional spread on clinical or radiographic evaluation $(8,10-15)$. There is a tendency that tongue cancer increases in young females in recent 2-3 decades (16-18). Thus, metastasis suppression is a main and urgent subject in the treatments of patients with tongue SCC.

The process of metastasis is complex and involves tumor growth, the extra-cellular matrix breakdown, invasion to the vessels, escape from immune surveillance, transport to other sites with adhesion to the vessel, subsequent invasion into an organ where tumor cells proliferate, grow and spread. Various molecules participate in the process but their roles remain incompletely understood. Tumor necrosis factor (TNF)- $\alpha$ is one of major regulators of inflammation, playing 
Table I. RT-PCR conditions.

\begin{tabular}{llcr}
\hline Gene & \multicolumn{1}{c}{ Primer sequences $\left(5^{\prime}-3{ }^{\prime}\right)$} & Annealing temperature $\left({ }^{\circ} \mathrm{C}\right)$ & Cycles \\
\hline TNF- $\alpha$ & $\begin{array}{l}\text { Forward: CGGGACGTCGAGCTGGCCGAGGAG } \\
\text { Reverse: TTGCAGTGTGTTATCCGTGCTGTC }\end{array}$ & 50 & 35 \\
TNFR-1 & $\begin{array}{l}\text { Forward: TACATTGCAGCCTCTGCCTC } \\
\text { Reverse: AGAGCTTGGACTTCCACCGT }\end{array}$ & 50 & 35 \\
TNFR-2 & $\begin{array}{l}\text { Forward: ACATCAGACGTGGTGTGCAA } \\
\text { Reverse: CCAACTGGAAGAGCGAAGTC }\end{array}$ & 50 & 35 \\
Angpt14 & $\begin{array}{l}\text { Forward: CCTCAGGGGTCTCCGCCATTTT } \\
\beta \text {-actin }\end{array}$ & $\begin{array}{l}\text { Reverse: GGGCCGGTTGAAGTCCACTGA } \\
\text { Forward: CCAAGGCCAACCGCGAGAAGATTGAC } \\
\text { Reverse: AGGGTACATGGTGGTGCCGCCAGAC }\end{array}$ & 60 \\
\hline
\end{tabular}

in the cytokine network. TNF- $\alpha$ is synthesized primarily by immune cells as a 34-kDa type II transmembrane protein (19) and a soluble form of the C-terminal $17 \mathrm{kDa}$ portion is released from cells through cleavage by TNF- $\alpha$-converting enzyme (20). TNF- $\alpha$ forms a homotrimer that activates cells via two distinct receptors (21). TNFR1 (p55, CD120a) binds the soluble ligand and is expressed on most cells, and TNFR2 (p75, CD120b) primarily binds the transmembrane form and is found on hematopoietic cells (22). TNF- $\alpha$ required high doses or injection to the tumor tissue for induction of hemorrhagic tumor necrosis (19). In contrast, TNF- $\alpha$ at low doses exerted angiogenic activity in both the rabbit cornea and chick chorioallantoic membrane models $(23,24)$. By treating tumor cells or mice TNF- $\alpha$ augmented the metastatic activity of transplanted tumor cells $(25,26)$. These reports suggest TNF- $\alpha$ activity for cancer progression. Thus, whether TNF- $\alpha$ is an anticancer molecule or therapeutic target is an important issue in the treatment of cancer including tongue SCC.

To study a relationship between TNF- $\alpha$ and tongue cancer metastasis, we made highly metastatic oral squamous cell carcinoma (OSCC) cells by repeated implantation of lymph node-metastasized OSCC cells into a nude mouse tongue (27) and investigated secretion of TNF- $\alpha$ and MMPs, and expression of TNF- $\alpha$ receptors and molecules involved in TNF- $\alpha$ signaling pathway. Moreover, mRNA expression in highly metastatic OSCC cells after lung metastasis was measured by DNA microarray method, and migration activity by wound healing assay.

\section{Materials and methods}

Preparation of highly metastatic cell lines from a GFP-expressing OSCC cell line. The human OSCC cell line SAS cells were transfected with the pAcGFP1-C1 vector (Clontech Laboratories, Mountain View, CA, USA) using FuGENE 6 (Roche Diagnostics, Indianapolis, IN, USA), then the cells with strong GFP fluorescence were isolated by flow cytometry. The cells were selected in Dulbecco's modified Eagle's medium (DMEM) supplemented with $1 \mathrm{mg} / \mathrm{ml} \mathrm{G} 418$ (Life Technologies, Grand Island, NY, USA). The cells with bright GFP were designated GSAS and used as the parental cells. Highly metastatic cell lines were prepared according the method previously described (27). Briefly, GSAS cells $\left(5.0 \times 10^{5}\right.$ in $50 \mu \mathrm{l}$ serum-free DMEM medium were injected into the tongue of a nude mouse and after 21 days were harvested from metastasized cervical lymph nodes. These GSAS cells were cultured in DMEM medium supplemented with $10 \% \mathrm{FBS}$ and transplanted into the tongue of another nude mouse. This procedure was repeated and GSAS cells after 5 passages were referred to as GSAS/N5. To obtain a lung metastatic cell line, GSAS/N5 was injected into the tongue of a nude mouse. The cells that metastasized to the lungs (GSAS/L) were cultured for use.

TNF- $\alpha$ assay. TNF- $\alpha$ in the GSAS culture medium was assessed by enzyme-linked immunosorbent assay (ELISA) using Human TNF- $\alpha$ Quatikaine ELISA kit (R\&D Systems, Inc., Minneapolis, MN, USA). Cells $\left(2.0 \times 10^{6}\right)$ were cultured in serum-free DMEM medium for $24 \mathrm{~h}$ and $25 \mu \mathrm{l}$ of the supernatant was incubated in an anti-TNF- $\alpha$ antibody-adsorbed well for $4 \mathrm{~h}$ at room temperature, followed by washing. Biotin-labeled anti-TNF- $\alpha$ antibody was poured into the well, and after washing streptavidin-labeled peroxidese was incubated for $10 \mathrm{~min}$ in the well. After washing, $100 \mu 1$ of TMB solution was added and incubated for $10 \mathrm{~min}$, followed by $50 \mu \mathrm{l}$ of $2 \mathrm{M} \mathrm{HCl}$. The absorbance of the solution was measured at $450 \mathrm{~nm}$.

Total RNA extraction and reverse transcription-PCR. The cells were incubated in serum-free DMEM in the presence or absence of $100 \mu \mathrm{M}$ NBD peptide (Imgenex Corp., San Diego, CA, USA). After $24 \mathrm{~h}$, total RNA was isolated using the RNeasy Mini kit (Qiagen, Valencia, CA, USA). The RNA quantity, purity, and integrity were evaluated using a NanoDrop spectrophotometer (Thermo Fisher Scientific, Inc., Waltham, MA, USA). Complementary DNA was synthesized from total RNA using the PrimeScript RT reagent kit (Takara Bio Inc., Shiga, Japan). Gene-specific primer sets were designed using the Custom Primers software program (Invitrogen, Carlsbad, CA, USA). The primer sequences and the amplification conditions are shown in Table I. The expression of $\beta$-actin was used as an internal control.

Flow cytometry. GSA/L cells were treated for $30 \mathrm{~min}$ with a rabbit anti-Angptl4 antibody (Abgent, Inc., San Diego, CA, USA) or a control rabbit IgG (Dako Corp., Carpinteria, CA, 
USA), followed by washing with PBS twice and incubation with phycoerythrin-conjugated anti-rabbit IgG (Santa Cruz Biotechnology). Angptl4 antigen was quantified by FACScan (BD Biosciences, San Jose, CA, USA).

Western blotting. GSAS, GSAS/N3 and GSAS/N5 cells $\left(2.0 \times 10^{6}\right)$ were cultured in serum-free DMEM medium for $24 \mathrm{~h}$. Cell extracts were analyzed in an SDS-polyacrylamide gel and transferred onto a nitrocellulose membrane (Bio-Rad Laboratories, Hercules, CA, USA). After blocking with 5\% skim milk, the membrane was incubated overnight with the first antibody against Akt (1:1,000; Cell Signaling Technology, Boston, MA, USA), phosho-Akt (1:1,000; Santa Cruz Biotechnology, Dallas, TX, USA), phospho-IKK $\alpha / \beta(1: 1,000$; Cell Signaling Technology), or $\beta$-actin (1:5,000; SigmaAldrich, St. Louis, MO, USA). After washing, the membrane was treated for $1 \mathrm{~h}$ with HRP-labeled second antibody (EnVision+, Dako Corp.). Bands were visualized using ECL (GE Healthcare, Buckinghamshire, UK).

Electrophoretic mobility shift assay (EMSA). GSAS, GSAS/N3 and GSAS/N5 cells $\left(2.0 \times 10^{6}\right)$ were cultured in serum-free DMEM medium for $24 \mathrm{~h}$. Nuclear extracts were prepared using the NE-PER ${ }^{\text {TM }}$ Nuclear and Cytoplasmic Extraction reagents (Pierce Chemical Co., Dallas, TX, USA). The DNA binding reaction was performed with a biotin end-labeled $\mathrm{NF}-\kappa \mathrm{B}$ oligonucleotide (5'-AGCTTGGGGACTTTCCGAG-3') using a LightShift ${ }^{\mathrm{TM}}$ Chemiluminescent EMSA kit (Pierce Chemical). A total of $20 \mu \mathrm{l}$ of the extracts was electrophoresed in $6 \%$ polyacrylamide gels and transferred onto a nitrocellulose membrane (Bio-Rad Laboratories). Biotin-labeled DNA was detected with the Chemiluminescent Nucleic Acid Detection Module (Pierce Chemical). For supershift reactions, extracts were preincubated with an anti-p65 antibody (Santa Cruz Biotechnology) for $20 \mathrm{~min}$. All of the above procedures were done according to the manufacturer's protocols.

Gelatin zymography. Cells were seeded in a well of a 24-well plate to form a subconfluent sheet, then cultured in serum-free DMEM medium containing $0.5 \%$ BSA for $24 \mathrm{~h}$, followed by a 24-h incubation in $10 \mathrm{ng} / \mathrm{ml} \mathrm{TNF-} \alpha$ in the presence or absence of $100 \mu \mathrm{M}$ NBD peptide. The supernatant was obtained by centrifugation. To adjust the sample conditions, cells in a well were treated with $50 \mathrm{mM}$ Tris- $\mathrm{HCl}, \mathrm{pH} 6.8,2 \%$ SDS, $10 \%$ glycerol and protein amount was measured using DC protein assay (Bio-Rad Laboratories). Supernatant samples were diluted with 50 mM Tris-HCl, pH 6.8, 10\% SDS, 50\% glycerol to adjust to a same concentration per the protein amount of the cells in a well and $40 \mu \mathrm{l}$ of the sample was electrophoresed in a $10 \%$ SDS polyacrylamide gel containing $1 \mathrm{mg} / \mathrm{ml}$ gelatin. After washing twice in $10 \mathrm{mM}$ Tris- $\mathrm{HCl}, \mathrm{pH} 8.0,2.5 \%$ Triton $\mathrm{X}-100$, the gel was incubated in $50 \mathrm{mM}$ Tris- $\mathrm{HCl}, \mathrm{pH} 8.0$, $0.5 \mathrm{mM} \mathrm{CaCl}_{2}, 1 \mu \mathrm{M} \mathrm{ZnCl}_{2}$ at $37^{\circ} \mathrm{C}$ for $16 \mathrm{~h}$. Then, the gel was stained in Coomassie brilliant blue solution. To determine the MMPs, standard pro-MMP-2, active MMP-2 and pro-MMP-9 (Cosmo Bio Co., Ltd., Tokyo, Japan) were electrophoresed in the same gel together with the samples.

Invasion assay. CytoSelect ${ }^{\mathrm{TM}}$ 24-well Cell Invasion Assay (Cell Biolabs, Inc., San Diego, CA, USA) was used to measure cancer cell invasion activity according to the manufacturer's instructions. Cells $\left(2.0 \times 10^{5}\right)$ were suspended in serum-free DMEM, and then seeded into the upper chamber in the presence or absence of $100 \mu \mathrm{M}$ NBD peptide. Serum-free DMEM was placed in the lower chamber. After incubation for $24 \mathrm{~h}$, cells that invaded through Matrigel (BD Biosciences) layer to the lower surface of the $8 \mu \mathrm{m}$-pored membrane partitioning the chambers were fixed in $100 \%$ methanol, stained with $1 \%$ toluidine blue and counted in 4 microscopic fields (x400). The average cell number per a field in triplicate assay is shown.

Gene expression microarrays. Total RNA of GSAS, GSAS/N3, GSAS/N5 or GSAS/L cells was isolated using the RNeasy Mini kit (Qiagen). The RNA quantity, purity, and integrity were evaluated using a NanoDrop spectrophotometer (Thermo Fisher Scientific). The cRNA was amplified, labelled, and hybridised by an Agilent Human GE 4x44K v2 Microarray (Agilent Technologies, Santa Clara, CA, USA) according to the manufacturer's instructions. Signals of probes in all hybridised microarrays were scanned by an Agilent scanner and calculated using Feature Extraction Software version 9.5.1.1 (Agilent Technologies).

Wound healing assay. GSAS, GSAS/N3 and GSAS/N5 cells $\left(5.0 \times 10^{5}\right)$ were seeded in 6 -well plates and were cultured in DMEM containing $10 \%$ of FBS for $24 \mathrm{~h}$. A line was scratched with a yellow pipette tip in the $70-80 \%$ confluent monolayer, and the cellular debris were removed by washing with serum-free DMEM. Then, the cell sheets were incubated in serum-free DMEM and the cell migration into the wound area was photographed with a phase-contrast microscope for $24 \mathrm{~h}$. The distance between the cell migration fronts of both sides was measured vertically against the initial scratch border at three points at random after $24 \mathrm{~h}$ from scratching and the percentage of the average distance vs. the distance between the initial scratch borders was calculated. All the assays were performed as a set of three independent experiments.

Statistical analysis. Statistical analysis was performed using the unpaired Student's t-test. Values are expressed as means $\pm \mathrm{SD}$.

\section{Results}

Enhancement of invasive activity of GSAS/N5 cells. High invasiveness facilitates spread and metastasis of cancer cells, thus, invasive activity was measured for GSAS cells and GSAS/N5 cells and compared between them. Invasive activity of GSAS/N5 cells was >7-fold higher than that of GSAS cells (Fig. 1). The invasive activity of GSAS/N5 cells was mostly inhibited in the presence of soluble TNF-R1 and the inhibitory effect of the receptor was decreased by TNF- $\alpha$ addition (Fig. 1B). The result indicated that invasive activity was enhanced in GSAS/N5 cells and the enhanced invasive activity of the highly metastatic cancer cells was mainly dependent on TNF-R1.

Elevation of TNF-R1-NF- $\kappa B$ pathway and TNF- $\alpha$ secretion in GSAS/N cells. TNFR1-dependent enhancement of 

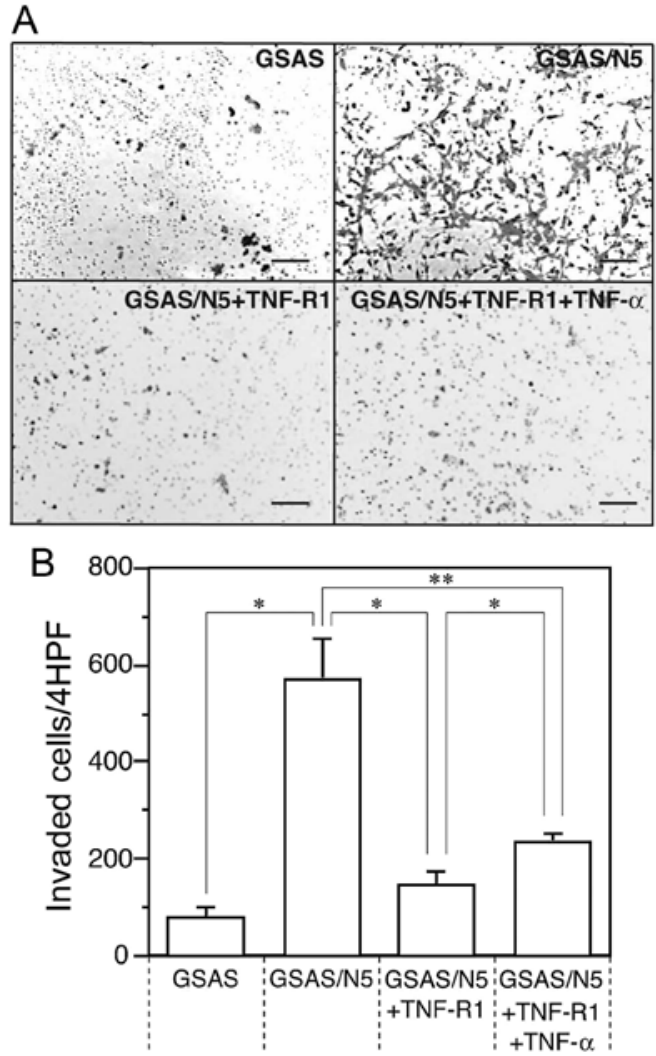

Figure 1. Invasive activity of cancer cells. Cells were suspended in serumfree DMEM, and then seeded into the upper chamber in the presence or absence of TNF-R1 (100 ng/ml) or TNF- $\alpha(10 \mathrm{ng} / \mathrm{ml})$. (A) Images of representative lower surface of the membrane (pore size, $8 \mu \mathrm{m}$ ) to which cells invaded through Matrigel layer. Scale bar, $100 \mu \mathrm{m}$. (B) Cells that invaded through Matrigel layer to the lower surface of the membrane after incubation for $24 \mathrm{~h}$ were counted in 4 microscopic fields $(\mathrm{x} 400)$ and the average cell number per a field was shown. Values indicate the average $\pm \operatorname{SD}(n=4)$. ${ }^{*} \mathrm{P}<0.002,{ }^{* *} \mathrm{P}<0.004$.

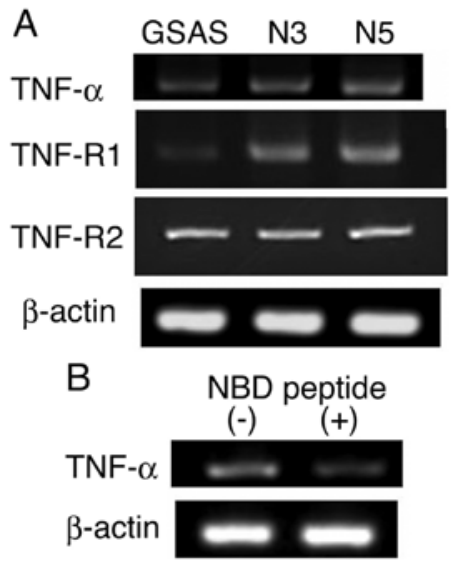

Figure 2. Cancer cell expression of TNF- $\alpha$, TNF-R1 and TNF-R2 mRNA and inhibition of TNF- $\alpha$ mRNA expression by NBD peptide. (A) Cancer cells were incubated in serum-free DMEM for $24 \mathrm{~h}$. TNF- $\alpha$, TNF-R1 and TNF-R2 mRNAs were assayed by RT-PCR. (B) GSAS/N5 cells were incubated in serum-free DMEM for $24 \mathrm{~h}$ in the presence or absence of $100 \mu \mathrm{M}$ NBD peptide. Then, TNF- $\alpha$ mRNA was assayed by RT-PCR.

GSAS/N5 cell invasive activity suggested involvement of TNF- $\alpha-T N F-R 1$ system and elevation of the TNF-R1-initiated signaling pathway in the highly metastatic cancer cells. Hence,
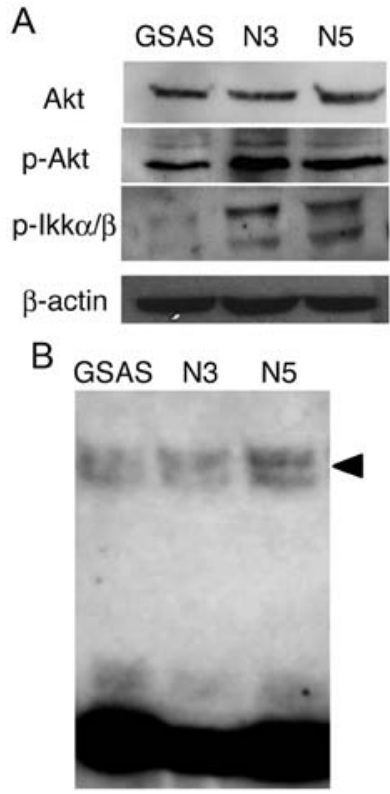

Figure 3. Cancer cell expression of molecules in the signaling pathway from TNF-R1 to NF- $\kappa$ B. (A) Cancer cells were cultured in serum-free DMEM medium for $24 \mathrm{~h}$ and Akt, phospho-Akt, and phospho-IKK $\alpha / \beta$ in the extracts of the cells were assayed by western blotting. (B) Cancer cells were cultured in serum-free DMEM medium for $24 \mathrm{~h}$ and p50/p65 in the nuclear extracts was assessed by electrophoretic mobility shift assay.

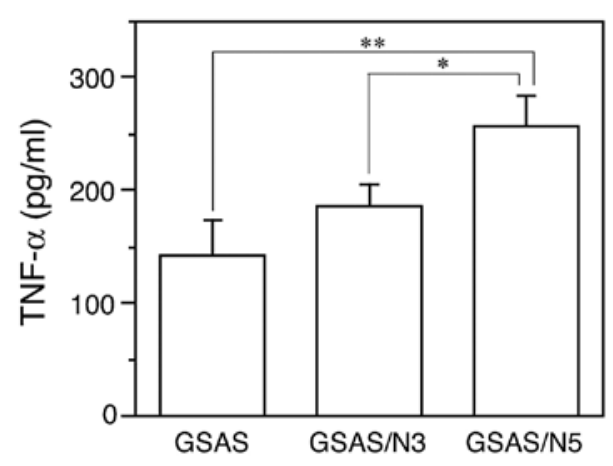

Figure 4. TNF- $\alpha$ release from cancer cells. Cells were cultured in serumfree DMEM medium for $24 \mathrm{~h}$ and TNF- $\alpha$ in the medium was measured by ELISA. Values indicate the average $\pm \mathrm{SD}(\mathrm{n}=3)$. ${ }^{*} \mathrm{P}<0.02,{ }^{* *} \mathrm{P}<0.008$.

this system of the cancer cells was investigated. TNF- $\alpha$ and the receptor TNF-R1 mRNA expression increased in GSAS/N3 and GSAS/N5 cells in comparison with GSAS cells, but TNF-R2 mRNA expression did not change among the three GSAS cells (Fig. 2A). Suppression of TNF- $\alpha$ mRNA expression by NBD peptide (Fig. 2B) that inhibits NF- $\kappa$ B activation (28) indicated that increase of TNF- $\alpha$ mRNA expression was caused by NF- $\kappa \mathrm{B}$ activation. The signaling pathway triggered by binding of TNF- $\alpha$ to TNFR1 mediates NF- $\kappa \mathrm{B}$ activation in human head and neck squamous cell carcinoma (29). Thus, molecules participating in the signaling pathway from TNFR1 to NF- $\kappa \mathrm{B}$ (30) were examined. Phospho-Akt protein increased in GSAS/N3 and GSAS/N5 cells, but Akt expression did not change (Fig. 3A). Phospho-IKK $\alpha / \beta$ was significantly increased in the highly metastatic cells, whereas it was negligible in GSAS cells (Fig. 3A). Expression of p50/p65, components of NF-кB (29), was enhanced in GSAS/N5 cells (Fig. 3B). These 
Table II. Gene expression microarrays.

\begin{tabular}{|c|c|c|c|c|c|c|c|}
\hline \multirow[b]{2}{*}{ Gene } & \multicolumn{3}{|c|}{ Signal } & \multicolumn{2}{|c|}{ GSAS/N5 vs. GSAS } & \multicolumn{2}{|c|}{ GSAS/L vs. GSAS } \\
\hline & GSAS & GSAS/N5 & GSAS/L & Ratio & Z-score & Ratio & Z-score \\
\hline Angpt14 & 120.180 & 677.890 & 17002.502 & 5.64 & 3.6 & 141.48 & 14.8 \\
\hline HSPA1A & 1692.248 & 16530.238 & 67702.449 & 9.77 & 6.2 & 40.01 & 13.3 \\
\hline VNN1 & 10.544 & 46.645 & 388.448 & 4.42 & 2.1 & 36.84 & 4.8 \\
\hline GJB4 & 77.626 & 301.386 & 2711.984 & 3.88 & 2.8 & 34.94 & 8.9 \\
\hline HSPA1B & 1255.094 & 5619.184 & 20255.974 & 4.48 & 4.1 & 16.14 & 8.3 \\
\hline NLRP3 & 23.420 & 123.228 & 291.084 & 5.26 & 2.3 & 12.43 & 5.6 \\
\hline TNFAIP3 & 104.419 & 305.699 & 1274.084 & 2.93 & 2.2 & 12.20 & 6.3 \\
\hline ZBED2 & 16.635 & 187.705 & 183.027 & 11.28 & 3.3 & 11.00 & 3.2 \\
\hline GRHL3 & 49.419 & 190.636 & 485.379 & 3.86 & 2.8 & 9.82 & 5.1 \\
\hline ZMAT4 & 3.177 & 49.333 & 31.066 & 15.53 & 2.5 & 9.78 & 2.1 \\
\hline
\end{tabular}

Angptl4, angiopoietin-like 4; HSPA1A, heat shock $70 \mathrm{kDa}$ protein 1A; VNN1, vanin 1; GJB4, gap junction protein, $\beta$ 4; HSPA1B, heat shock $70 \mathrm{kDa}$ protein 1B; NLRP3, NLR family pyrin domain containing 3; TNFAIP3, tumor necrosis factor $\alpha$-induced protein 3; ZBED2, zinc finger BED-type containing 2; GRHL3, grainyhead-like 3; ZMAT4, zinc finger matrin-type 4.

results indicated elevation of the signaling pathway to $\mathrm{NF}-\kappa \mathrm{B}$ and resultant increase of $\mathrm{NF}-\kappa \mathrm{B}$ activation in the highly metastatic oral SCC cells. NF- $\kappa \mathrm{B}$ activation leads to TNF- $\alpha$ production in cancer cells $(31,32)$, thus, $\mathrm{TNF}-\alpha$ secretion from the cancer cells was measured. In agreement with increased TNF- $\alpha$ mRNA expression (Fig. 2A) GSAS/N5 secreted significantly more TNF- $\alpha$ into the culture medium than GSAS and GSAS/N3 (Fig. 4).

Enhancement of active MMP release from GSAS/N5 cells by TNF- $\alpha$ and its inhibition by NBD peptide. Elevation of TNF-R1-NF- $\kappa$ B pathway in GSAS/N5 cells suggested that TNF- $\alpha$ stimulation was associated with enhanced invasive activity of the cells. We previously showed that elevated mRNA expression of MMP-2 and MMP-9 in GSAS/N5 cells (27). We examined whether the cancer cells secreted active forms of these MMPs by TNF- $\alpha$. By stimulation with TNF- $\alpha$, cancer cells secreted active MMPs that were converted from latent forms; GSAS/N5 cells released more active MMPs than other cells (Fig. 5). NBD peptide induced pronounced inhibition of TNF- $\alpha$-elicited active MMP-2 and MMP-9 secretion from the cancer cells (Fig. 5), which indicated a close association of TNF- $\alpha$-triggered NF- $\kappa \mathrm{B}$ activation to upregulation of active MMP release from the cancer cells.

Elevated angiopoietin-like 4 (Angptl4) expression and mobility of GSAS/L cells. To study tongue cancer metastasis further, we made another highly metastatic GSAS cell line (GSAS/L), which were GSAS/N5 cells that metastasized to the lung by implantation into a nude mouse tongue. GSAS, GSAS/N5 and GSAS/L cells were examined for exhaustive mRNA expression by the microarray assay and mRNAs that increased in comparison with GSAS cell mRNAs were sought. Table II shows the ten highest increase ratio mRNAs of GSAS/L cell and corresponding mRNAs of GSAS/N5 cells. This assay revealed mRNA elevation of several genes in the

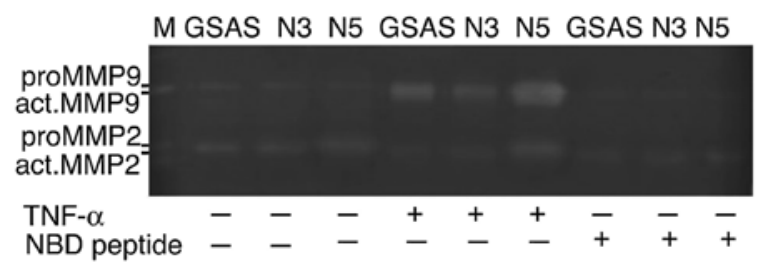

Figure 5. Release of active MMP-2 and MMP-9 from cancer cells by stimulation with TNF- $\alpha$. Cells were cultured in serum-free DMEM medium containing $0.5 \%$ BSA for $24 \mathrm{~h}$, followed by a $24-\mathrm{h}$ incubation in $10 \mathrm{ng} / \mathrm{ml}$ TNF- $\alpha$ in the presence or absence of $100 \mu \mathrm{M}$ NBD peptide. Then, the supernatant of the cell-cultured medium was analyzed by gelatin zymography.

highly metastatic cells and Angptl4 increased most among the mRNAs. Angpt14 mRNA expression of GSAS/L increased 141-fold for GSAS and 25-fold for GSAS/N5. Indeed, high expression of Angptl4 mRNA and the protein were confirmed in GSAS/L cells but GSAS cell Angpt14 mRNA expression was faint (Fig. 6). To study GSAS/L cells further, migration activity of the cells was investigated. In the scratch assay GSAS/L cells migrated more rapidly than GSAS/N5 and GSAS cells (Fig. 7). These results may suggest that the lung metastatic activity of GSAS/L is associated with enhancement of Angptl4 expression and cell mobility.

\section{Discussion}

We revealed enhancement of invasive activity in the highly metastatic OSCC cells (Fig. 1) accompanying elevated TNF- $\alpha$ signaling via TNFR1 (Fig. 2A), leading to NF- $\kappa$ B activation through phospholylation of Akt and IKK $\alpha / \beta$ (Fig. 3). The increase of TNF- $\alpha$ mRNA expression (Fig. 2A) and protein secretion (Fig. 4) in relation to elevated $N F-\kappa B$ activation (Fig. 3B) agrees with that NF- $\mathrm{B}$ activation leading to TNF- $\alpha$ production in tumor cells $(31,32)$. NF- $\kappa \mathrm{B}$ is a key regulator of MMP-2 and MMP-9 expression $(33,34)$, even in SAS cells (35) 

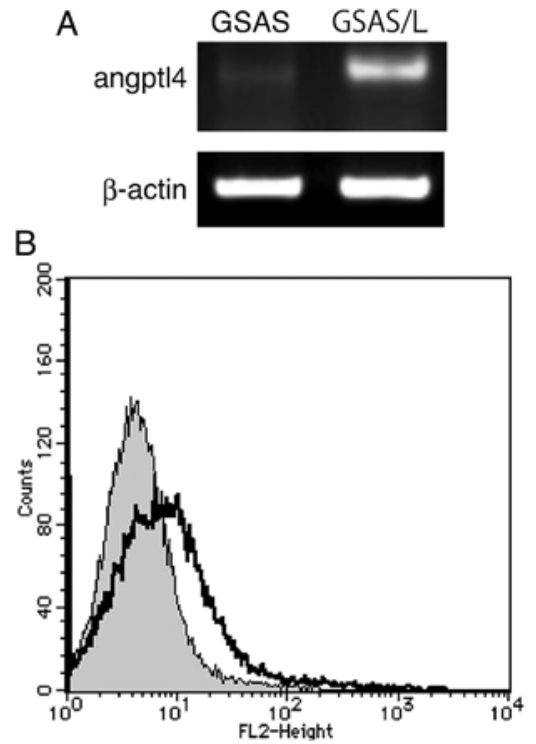

Figure 6. Angiopoietin-like 4 (Angpl4) expression of GSAS/L cells. (A) Angpl4 mRNA expression by RT-PCR. (B) Angpl4 protein expression by flow cytometry. Bold line and fine line indicate anti-Angpl4 antibody and control rabbit IgG, respectively.

used in the present study, which suggests that the high NF- $\mathrm{kB}$ level of GSAS/N5 cells implicated secretion enhancement of these proteases from the cells (Fig. 5). Upregulation of MMP-2 and MMP-9 expression is associated with tumor invasion and metastasis $(36,37)$. Accordingly, elevated secretion of active forms of these proteases in the GSAS/N5 cells (Fig. 5) likely accounts for high invasive (Fig. 1) and metastatic (27) activities of the cells.

We have shown that NF- $\mathrm{KB}$ level was elevated as GSAS cell metastasis passage advanced (Fig. 3B). The highly metastatic GSAS cells, particularly GSAS/N5, secrete more TNF- $\alpha$ (Fig. 4) together with increased expression of TNFR1 (Fig. 2A), the receptor for soluble TNF- $\alpha$ (22). The increase of TNF- $\alpha$ release brings about further NF- $\kappa$ B activation via TNFR1 signaling pathway in the cells and resultant elevation of MMPs secretion. As an autocrine TNF- $\alpha$ from tumor cells stimulated by this cytokine was reported (38), TNF- $\alpha$ release from the highly metastatic cells is possibly amplified in an autocrine mannaer. These findings suggest an autoactivation mechanism for TNF- $\alpha$-triggered NF- $\mathrm{KB}$ activation in these cells. This may be an underlying mechanism by which GSAS/N3 and GSAS/N5 cells exert high invasive and metastatic activities. Such a positive feedback between NF- $\mathrm{KB}$ and TNF- $\alpha$ was reported in leukemia-initiating cells and contributes to leukemia progression (32). The present study suggests that this mechanism is present in the oral cancer cells and associated with enhanced secretion of active MMPs, augmenting invasion and probably metastasis of the malignant cells. In addition, the stimulative effect of TNF- $\alpha$ on the epithelial-mesenchymal transition (38) may also be augmented through the auto-activation mechanism, participating in the progression of the highly metastatic cancer cells.

Angptl 4 is a member of proteins which are structurally similar to the angiopoietins but they do not bind to the angiopoietin receptors, namely the tyrosine kinase with immunoglobulinlike and EGF-like domain 1 (Tiel) and the endothelial-specific
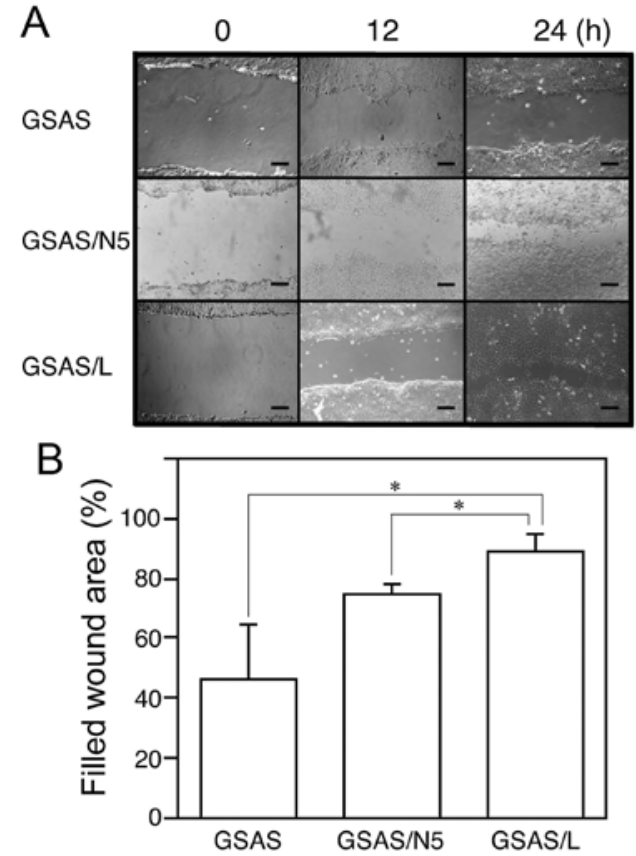

Figure 7. Cancer cell migration activity measured by wound healing assay. (A) Images of representative cell migration to the scratched area. Scale bar, $100 \mu \mathrm{m}$. (B) The distance between the cell migration fronts of both sides was measured vertically against the initial scratch border at three points at random after $24 \mathrm{~h}$ from scratching and the percentage of the average distance vs. the distance between the initial scratch borders was calculated. Values indicate the average $\pm \operatorname{SD}(n=3) .{ }^{*} \mathrm{P}<0.02$.

receptor tyrosine kinase (TEK or Tie2) (39). Angptl4 is a critical mediator in the transmigration process $(40,41)$ and promotes transendothelial migration of cancer cells through the upregulation of vascular endothelial adhesion molecule 1 (VCAM-1) expression on endothelial cells (42). The increase of VCAM-1 on endothelial cells facilitates the attachment of cancer cells in the circulation to the vessels, allowing subsequent extravasation and tumor establishment. Clinical studies showed correlation of Angptl4 expression with venous and lymphatic invasion in human squamous cell carcinoma (43). Moreover, Angpt14 was reported as a lung metastasis gene in breast cancer (44). Considering these Angpt14 activities to support cancer progression, a high expression of the molecule (Table II and Fig. 6) in GSAS/L cells seems to be associated with metastasis of the OSCC cells, particularly to lungs, in addition to the enhanced invasiveness (Fig. 7).

In the highly metastatic OSCC cells, the elevated TNFR1 signaling pathway enhanced resultant NF- $\mathrm{KB}$ activation that was amplified through the auto-activation mechanism, leading to increase of active MMP-2 and MMP-9 secretion and invasive activity. Angpt14 mRNA was multiplied 25-fold in GSAS/L cells in comparison with GSAS/N5 cells, suggesting an involvement of this molecule in lung metastasis. The high expression level of Angptl4 was predictive of poor prognosis and prognostic of poor survival in patients with tongue cancer (45). These results may indicate that TNF- $\alpha$, TNFR1 and Angpt14 were therapeutic targets of OSCC, including tongue cancers. Thus, blocking the TNF- $\alpha$-TNFR1 system and Angptl4 with antibodies and receptor antagonists is possibly effective on the treatment of OSCC, inhibiting progression of the cancer. 


\section{Acknowledgements}

The present study was supported in part by the Japanese Science Progress Society KAKENHI Grant (26463049) to T.T.

\section{References}

1. Siegel RL, Miller KD and Jemal A: Cancer statistics, 2015. CA Cancer J Clin 65: 5-29, 2015.

2. Kalnins IK, Leonard AG, Sako K, Razack MS and Shedd DP Correlation between prognosis and degree of lymph node involvement in carcinoma of the oral cavity. Am J Surg 134 450-454, 1977.

3. Schuller DE, McGuirt WF, McCabe BF and Young D: The prognostic significance of metastatic cervical lymph nodes. Laryngoscope 90: 557-570, 1980.

4. Snow GB, Annyas AA, van Slooten EA, Bartelink H and Hart AA: Prognostic factors of neck node metastasis. Clin Otolaryngol Allied Sci 7: 185-192, 1982.

5. Grandi C, Alloisio M, Moglia D, Podrecca S, Sala L, Salvatori P and Molinari R: Prognostic significance of lymphatic spread in head and neck carcinomas: Therapeutic implications. Head Neck Surg 8: 67-73, 1985.

6. Chi AC, Day TA and Neville BW: Oral cavity and oropharyngeal squamous cell carcinoma - an update. CA Cancer J Clin 65: 401-421, 2015.

7. Sano D and Myers JN: Metastasis of squamous cell carcinoma of the oral tongue. Cancer Metastasis Rev 26: 645-662, 2007.

8. Ho CM, Lam KH, Wei WI, Lau SK and Lam LK: Occult lymph node metastasis in small oral tongue cancers. Head Neck 14: 359-363, 1992.

9. Myers EN and Simental AA Jr: Cancer of the oral cavity. In: Cancer of the head and neck. 4th edition. Myers EN, Suen JY, Myers JN and Hanna EY (eds). Elsevier, pp279-319, 2004.

10. Teichgraeber JF and Clairmont AA: The incidence of occult metastases for cancer of the oral tongue and floor of the mouth: Treatment rationale. Head Neck Surg 7: 15-21, 1984.

11. Cunningham MJ, Johnson JT, Myers EN, Schramm VL Jr and Thearle PB: Cervical lymph node metastasis after local excision of early squamous cell carcinoma of the oral cavity. Am J Surg 152: 361-366, 1986.

12. Fakih AR, Rao RS and Patel AR: Prophylactic neck dissection in squamous cell carcinoma of oral tongue: A prospective randomized study. Semin Surg Oncol 5: 327-330, 1989.

13. Lydiatt DD, Robbins KT, Byers RM and Wolf PF: Treatment of stage I and II oral tongue cancer. Head Neck 15: 308-312, 1993.

14. Yuen AP, Wei WI, Wong YM and Tang KC: Elective neck dissection versus observation in the treatment of early oral tongue carcinoma. Head Neck 19: 583-588, 1997.

15. Yuen AP, Lam KY, Chan AC, Wei WI, Lam LK, Ho WK and Ho CM: Clinicopathological analysis of elective neck dissection for N0 neck of early oral tongue carcinoma. Am J Surg 177: 90-92, 1999.

16. Müller S, Pan Y, Li R and Chi AC; The Emory University Experience: Changing trends in oral squamous cell carcinoma with particular reference to young patients: 1971-2006. The Emory University experience. Head Neck Pathol 2: 60-66, 2008.

17. Patel SC, Carpenter WR, Tyree S, Couch ME, Weissler M, Hackman T, Hayes DN, Shores C and Chera BS: Increasing incidence of oral tongue squamous cell carcinoma in young white women, age 18 to 44 years. J Clin Oncol 29: 1488-1494, 2011.

18. Toporcov TN, Znaor A, Zhang ZF, Yu GP, Winn DM, Wei Q, Vilensky M, Vaughan T, Thomson P, Talamini R, et al: Risk factors for head and neck cancer in young adults: A pooled analysis in the INHANCE consortium. Int J Epidemiol 44: 169-185, 2015

19. Pennica D, Nedwin GE, Hayflick JS, Seeburg PH, Derynck R, Palladino MA, Kohr WJ, Aggarwal BB and Goeddel DV: Human tumour necrosis factor: Precursor structure, expression and homology to lymphotoxin. Nature 312: 724-729, 1984.

20. Black RA, Rauch CT, Kozlosky CJ, Peschon JJ, Slack JL, Wolfson MF, Castner BJ, Stocking KL, Reddy P, Srinivasan S, et al: A metalloproteinase disintegrin that releases tumournecrosis factor-alpha from cells. Nature 385: 729-733, 1997.

21. Locksley RM, Killeen N and Lenardo MJ: The TNF and TNF receptor superfamilies: Integrating mammalian biology. Cell 104: 487-501, 2001.
22. Balkwill F: Tumour necrosis factor and cancer. Nat Rev Cancer 9: 361-371, 2009.

23. Fràter-Schröder M, Risau W, Hallmann R, Gautschi $P$ and Böhlen P: Tumor necrosis factor type $\alpha$, a potent inhibitor of endothelial cell growth in vitro, is angiogenic in vivo. Proc Natl Acad Sci USA 84: 5277-5281, 1987.

24. Leibovich SJ, Polverini PJ, Shepard HM, Wiseman DM, Shively V and Nuseir N: Macrophage-induced angiogenesis is mediated by tumour necrosis factor-alpha. Nature 329: 630-632, 1987.

25. Malik STA, Naylor MS, East N, Oliff A and Balkwill FR: Cells secreting tumour necrosis factor show enhanced metastasis in nude mice. Eur J Cancer 26: 1031-1034, 1990.

26. Orosz P, Echtenacher B, Falk W, Rüschoff J, Weber D and Männel DN: Enhancement of experimental metastasis by tumor necrosis factor. J Exp Med 177: 1391-1398, 1993.

27. Tanaka T, Nakayama H, Yoshitake Y, Irie A, Nagata M, Kawahara K, Takamune Y, Yoshida R, Nakagawa Y, Ogi H, et al: Selective inhibition of nuclear factor- $\kappa \mathrm{B}$ by nuclear factor- $\kappa \mathrm{B}$ essential modulator-binding domain peptide suppresses the metastasis of highly metastatic oral squamous cell carcinoma. Cancer Sci 103: 455-463, 2012.

28. May MJ, D'Acquisto F, Madge LA, Glöckner J, Pober JS and Ghosh S: Selective inhibition of NF-kappaB activation by a peptide that blocks the interaction of NEMO with the IkappaB kinase complex. Science 289: 1550-1554, 2000.

29. Jackson-Bernitsas DG, Ichikawa H, Takada Y, Myers JN, Lin XL, Darnay BG, Chaturvedi MM and Aggarwal BB: Evidence that TNF-TNFR1-TRADD-TRAF2-RIP-TAK1-IKK pathway mediates constitutive NF-kappaB activation and proliferation in human head and neck squamous cell carcinoma. Oncogene 26: 1385-1397, 2007.

30. Rehman AO and Wang C-Y: SDF-1 $\alpha$ promotes invasion of head and neck squamous cell carcinoma by activating NF-kappaB. J Biol Chem 283: 19888-19894, 2008

31. Stathopoulos GT, Kollintza A, Moschos C, Psallidas I, Sherrill TP, Pitsinos EN, Vassiliou S, Karatza M, Papiris SA, Graf D, et al: Tumor necrosis factor-alpha promotes malignant pleural effusion. Cancer Res 67: 9825-9834, 2007.

32. Kagoya Y, Yoshimi A, Kataoka K, Nakagawa M, Kumano K, Arai S, Kobayashi H, Saito T, Iwakura Y and Kurokawa M: Positive feedback between NF- $\kappa \mathrm{B}$ and TNF- $\alpha$ promotes leukemia-initiating cell capacity. J Clin Invest 124: 528-542, 2014.

33. Epanchintsev A, Shyamsunder P, Verma RS and Lyakhovich A: IL-6, IL-8, MMP-2, MMP-9 are overexpressed in Fanconi anemia cells through a NF- $\mathrm{B} / \mathrm{TNF}-\alpha$ dependent mechanism. Mol Carcinog 54: 1686-1699, 2015.

34. Shi M, Cao M, Song J, Liu Q, Li H, Meng F, Pan Z, Bai J and Zheng J: PinX1 inhibits the invasion and metastasis of human breast cancer via suppressing NF- $\mathrm{KB} / \mathrm{MMP}-9$ signaling pathway. Mol Cancer 14: 66, 2015.

35. Lai WW, Hsu SC, Chueh FS, Chen YY, Yang JS, Lin JP, Lien JC, Tsai $\mathrm{CH}$ and Chung JG: Quercetin inhibits migration and invasion of SAS human oral cancer cells through inhibition of $\mathrm{NF}-\kappa \mathrm{B}$ and matrix metalloproteinase-2/-9 signaling pathways. Anticancer Res 33: 1941-1950, 2013.

36. Egeblad $\mathrm{M}$ and Werb Z: New functions for the matrix metalloproteinases in cancer progression. Nat Rev Cancer 2: 161-174, 2002.

37. Littlepage LE, Sternlicht MD, Rougier N, Phillips J, Gallo E, Yu Y, Williams K, Brenot A, Gordon JI and Werb Z: Matrix metalloproteinases contribute distinct roles in neuroendocrine prostate carcinogenesis, metastasis, and angiogenesis progression. Cancer Res 70: 2224-2234, 2010.

38. Bates RC and Mercurio AM: Tumor necrosis factor- $\alpha$ stimulates the epithelial-to-mesenchymal transition of human colonic organoids. Mol Biol Cell 14: 1790-1800, 2003.

39. Santulli G: Angiopoietin-like proteins: A comprehensive look. Front Endocrinol (Lausanne) 5: 4, 2014

40. Zhu P, Tan MJ, Huang RL, Tan CK, Chong HC, Pal M, Lam CR, Boukamp P, Pan JY, Tan SH, et al: Angiopoietinlike 4 protein elevates the prosurvival intracellular $\mathrm{O}_{2}^{-}: \mathrm{H}_{2} \mathrm{O}_{2}$ ratio and confers anoikis resistance to tumors. Cancer Cell 19: 401-415, 2011

41. Huang RL, Teo Z, Chong HC, Zhu P, Tan MJ, Tan CK, Lam CRI, Sng MK, Leong DTW, Tan SM, et al: ANGPTL4 modulates vascular junction integrity by integrin signaling and disruption of intercellular VE-cadherin and claudin-5 clusters. Blood 118: 3990-4002, 2011. 
42. Li H, Ge C, Zhao F, Yan M, Hu C, Jia D, Tian H, Zhu M, Chen T, Jiang G, et al: Hypoxia-inducible factor 1 alpha-activated angiopoietin-like protein 4 contributes to tumor metastasis via vascular cell adhesion molecule-1/integrin $\beta 1$ signaling in human hepatocellular carcinoma. Hepatology 54: 910-919, 2011.

43. Shibata K, Nakayama T, Hirakawa H, Hidaka S and Nagayasu T: Clinicopathological significance of angiopoietin-like protein 4 expression in oesophageal squamous cell carcinoma. J Clin Pathol 63: 1054-1058, 2010.
44. Minn AJ, Gupta GP, Padua D, Bos P, Nguyen DX, Nuyten D, Kreike B, Zhang Y, Wang Y, Ishwaran $\mathrm{H}$, et al: Lung metastasis genes couple breast tumor size and metastatic spread. Proc Nat Acad Sci USA 104: 6740-6745, 2007.

45. Wang Z, Han B, Zhang Z, Pan J and Xia H: Expression of angiopoietin-like 4 and tenascin $C$ but not cathepsin $\mathrm{C}$ mRNA predicts prognosis of oral tongue squamous cell carcinoma. Biomarkers 15: 39-46, 2010. 